\title{
ANALYSIS OF THERMAL PERFORMANCE OF WOOD AND EXPOSED STONE-WALLED BUILDINGS IN MOUNTAINOUS AREAS WITH BUILDING ENVELOP VARIATIONS
}

\author{
Hermawan Hermawan ${ }^{* 1}$, Hadiyanto Hadiyanto' ${ }^{2}$, Sunaryo Sunaryo ${ }^{1}$, Asyhar Kholil' \\ ${ }^{1}$ Qur'anic Science University, Wonosobo, Indonesia \\ ${ }^{2}$ Diponegoro University, Semarang, Indonesia
}

\begin{abstract}
A building's ability in creating thermal convenience will produce energy saving. Such an ability of a building is known as building thermal performance. Building thermal performance is highly influenced by the building envelop and environment temperature. This research aims at analyzing the thermal performance of two wood-and exposed stone-walled buildings in mountainous areas. The measurement uses a scaled prototype of $0.60 \mathrm{~m} \times 0.60 \mathrm{~m} \times 0.60$ meter size. Determination of building materials in accordance with local material conditions results from previous studies. The roof uses four material variations, namely roof tiles, zinc, asbestos and thatch. The floor uses three material variations, namely earth, concrete rebate and ceramic. There are a total of 32 building envelope variations. The measurement is performed for 24 hours for each variation model. The analysis uses a graphic and it will shows the difference between wood-and exposed stone-walled buildings. The research results generally show that air temperature inside wood building is higher than in exposed stone building. The highest indoor air temperature difference between the wood building and the exposed stone building is $0.37^{\circ} \mathrm{C}$. Finally, the building variation with the highest thermal performance is the one with zinc roof and earth floor.
\end{abstract}

Key words: thermal performance, local wall, highland

\section{INTRODUCTION}

Energy and thermal are two inseparable elements in building aspects. Thermal will cause the building to adapt. During dry season, buildings will try to make its indoor air temperature cooler. In a cold climate area, buildings will try to create a warmer indoor air temperature. This effort by a building in reducing or increasing air temperature aims at making its inhabitants comfortable. When these inhabitants feel uncomfortable, they will add more tools which can make them comfortable. The thermal comfort tools can be in the form of both cooling and heating devices. These two tools require fairly great amount of energy. Thermal comfort is needed to prevent the building from wasting energy. A building's ability in anticipating the environmental thermal condition is known as building thermal performance.

Building thermal performance is significantly influenced by building envelope be it in terms of its shape, materials, ornament or color [1-3]. Many studies on building envelope have been conducted and they have also found the building envelope design variations they believe capable of creating thermal comfort and energy saving $[4,5]$. Building envelope is a building's element in direct contact with the outer environment. This building envelope includes the building's roof, wall and floor. The roles played by this building envelope in creating thermal are varied, based on the forms and functions of building. A high or multi-story building will create wide a wall, and a low or one-story building will create a wider roof than its wall. Research on building envelope can be classified into several methods, namely field research, experimental research with building models and simulation research [6-8]. Each of these methods have their own strengths and weaknesses. The three methods of research on building envelope mostly use temperature variable for its measurement. This is because it is believed that temperature is the variable with greatest influence in the analysis of thermal comfort [9-10]. Temperature can be distinguished by its location, namely outdoor and indoor temperatures. Indoor temperature is influenced by the outdoor temperature and building envelope. The phase of change from outdoor to indoor temperatures constitutes a phase of creation of thermal comfort for the building's inhabitants. This phase of temperature change can be called as either heating or cooling [11]. The heating phase occurs when the building indoor temperature is higher than the building outdoor temperature. The cooling phase occurs when the building indoor temperature is lower than the building outdoor temperature.

In hot climate areas, the cooling phase is needed to allow the building's inhabitants to feel comfortable. When this is achieved, then the building successfully creates thermal comfort and the building performance is deemed good. In cold climate areas, the heating phase is needed to prevent the inhabitants from freezing and from needing heating/warming tools. The building designs in these two locations require different treatments, including the treatment in determining the good building envelope both in terms of its forms and materials. In high floor buildings, envelope forms should be carefully considered, yet in low buildings these envelope forms do not have too many variations. However, in low buildings, the materials 
become the main consideration when determining the building envelope.

Determining the materials in construction depends on the building owner's ability. It is quite often that the building owner pay little attention to this thermal comfort aspect in determining their building materials. They determine these materials, for example, merely for esthetic reasons. This is often the case with modern buildings. This is different from vernacular buildings which are created due to the continuous process of adaptation to the environment. Vernacular buildings always use local materials in their construction. Some studies suggest that vernacular buildings can deal with microclimate and can create thermal comfort for its inhabitants [12,13]. Currently, the tendency to use local materials is increasing for they enable the achievement of energy saving. Energy saving can be valued by the economic value of the materials used.

Many studies on thermal comfort in hot climate areas have been conducted. On the contrary, only a few studies have been conducted on envelope in buildings in cold climate areas. In tropical areas with its warm and humid tendency, some parts of them have low air temperature (cold). Such parts are located in mountainous areas. One of the areas in Indonesia surrounded by mountains is Wonosobo Regency, Central Java. It is in this Wonosobo
Regency that a highly historical tourism spot is located, i.e. Dieng Plateau. In this Dieng Plateau location, people still use furnace to warm their buildings. This shows that the performance of residences in Dieng Plateau is less successful that they need heating tools.

Seeing this phenomenon, it is necessary to conduct research to investigate the building envelope capable of making inhabitants of mountain slope comfortable from the perspective of its local material use. The objective of the study was to analyze the building envelope that is convenient for mountainous areas.

\section{MATERIALS AND METHODS}

The research conducted in dry season, from May 21 to June 5,2018 . The research used building prototypes of $0.60 \times 0.60 \times 0.60$ meter sizes. These building prototypes put in a mountain slope area. Two materials were chosen as the building wall, namely wood and exposed stone walls. They were chosen based on the local materials most mountainous people use [14]. Meanwhile, the building envelope variations distinguished in terms of the type of roof and floor materials. The roof materials included roof tile, zinc, asbestos and thatch. The floor materials included earth, wood, concrete rebate and ceramic. In total, there were 32 building envelope variations.

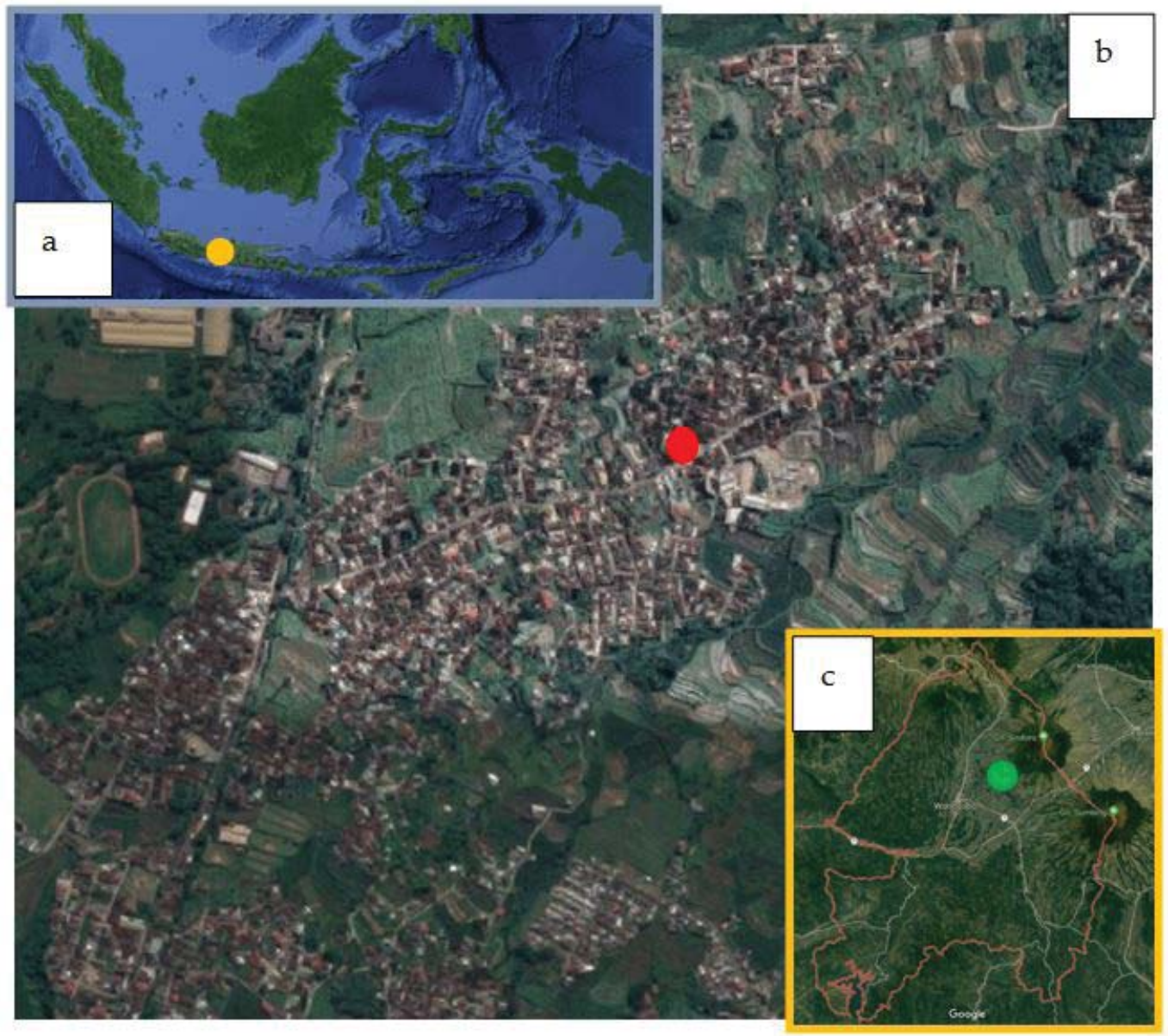

Figure 1: Research location, (a) Indonesia; (b) Central Java; (c) Wonosobo (Source : Google Map) 
Table 1: Building model variation

\begin{tabular}{|c|c|c|c|c|c|c|c|}
\hline Variation & Wall & Roof & Floor & Variation & Wall & Roof & Floor \\
\hline 1 & Wood & Roof tile & Earth & 17 & Exposed stone & Roof tile & Earth \\
\hline 2 & Wood & Roof tile & Wood & 18 & Exposed stone & Roof tile & Wood \\
\hline 3 & Wood & Roof tile & Concrete rebate & 19 & Exposed stone & Roof tile & Concrete rebate \\
\hline 4 & Wood & Roof tile & Ceramic & 20 & Exposed stone & Roof tile & Ceramic \\
\hline 5 & Wood & Zinc & Earth & 21 & Exposed stone & Zinc & Earth \\
\hline 6 & Wood & Zinc & Wood & 22 & Exposed stone & Zinc & Wood \\
\hline 7 & Wood & Zinc & Concrete rebate & 23 & Exposed stone & Zinc & Concrete rebate \\
\hline 8 & Wood & Zinc & Ceramic & 24 & Exposed stone & Zinc & Ceramic \\
\hline 9 & Wood & Asbestos & Earth & 25 & Exposed stone & Asbestos & Earth \\
\hline 10 & Wood & Asbestos & Wood & 26 & Exposed stone & Asbestos & Wood \\
\hline 11 & Wood & Asbestos & Concrete rebate & 27 & Exposed stone & Asbestos & Concrete rebate \\
\hline 12 & Wood & Asbestos & Ceramic & 28 & Exposed stone & Asbestos & Ceramic \\
\hline 13 & Wood & Thatch & Earth & 29 & Exposed stone & Thatch & Earth \\
\hline 14 & Wood & Thatch & Wood & 30 & Exposed stone & Thatch & Wood \\
\hline 15 & Wood & Thatch & Concrete rebate & 31 & Exposed stone & Thatch & Concrete rebate \\
\hline 16 & Wood & Thatch & Ceramic & 32 & Exposed stone & Thatch & Ceramic \\
\hline
\end{tabular}

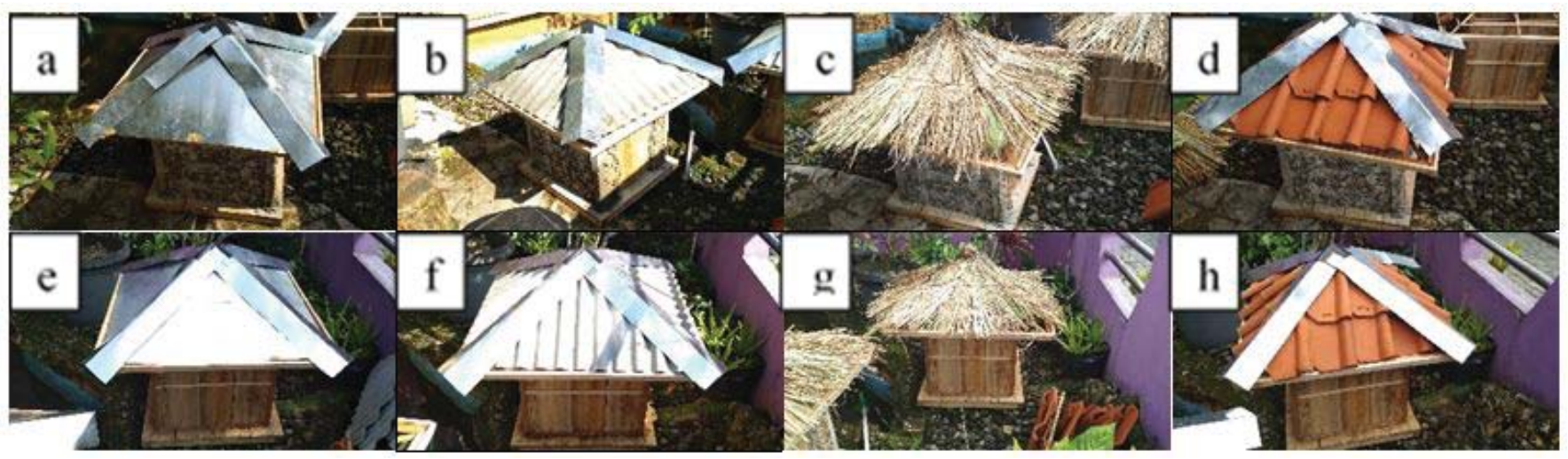

Figure 2: Roof variation of the building models, (a) Building with exposed stone wall and zinc roof; (b) Building with exposed stone wall and asbestos roof; (c) Building with exposed stone wall and thatch roof, (d) Building with exposed stone wall and roof tile; (e) Building with wood wall and zinc roof; (f) Building with wood wall and asbestos roof; (g) Building with wood wall and thatch roof; (h) Building with wood wall and roof tile.

The measurement was made by putting the tools in the middle of the building to obtain data on indoor temperature. This measurement used two thermal data logger tools set at each minute. The measurement was done for 1 one full day (24 hours). 1382 data of each building variation was obtained since some of the time is used to store the data. In total, the data on all building variations were 44224. The measurement of two building prototypes with the same roof and floor are done at one time. For example, on the first day the building prototypes measured were the one with wood wall, roof tile, earth floor together with the one with exposed stone wall, roof tile, and earth floor. A total of 16 days (384 hours) was needed to measure the 32 building prototype variations. The data were analyzed using graphics by observing the comparison of two building variations with the same roof and floor. From the comparison results, it can be seen the building with higher or lower temperature. Additionally, the difference between the two variations with the same roof and floor is calculated. The result can be deemed as the thermal performance difference between wood- and exposed stone-walled buildings.

\section{RESULTS AND DISCUSSION}

\section{Effect of Indoor Temperature}

The use of temperature as the core variable of research is consistent with another study which finds that temperature is the variable with most significant influence in analyzing thermal comfort. The temperature is measured both indoor and outdoor. The outdoor temperature is measured in two different places, namely the terrace and yard. The obtained outdoor temperature measurement shows irregularity. The highest outdoor temperature is from 9:00 am to $3: 00 \mathrm{pm}$, due to the sunlight during the 


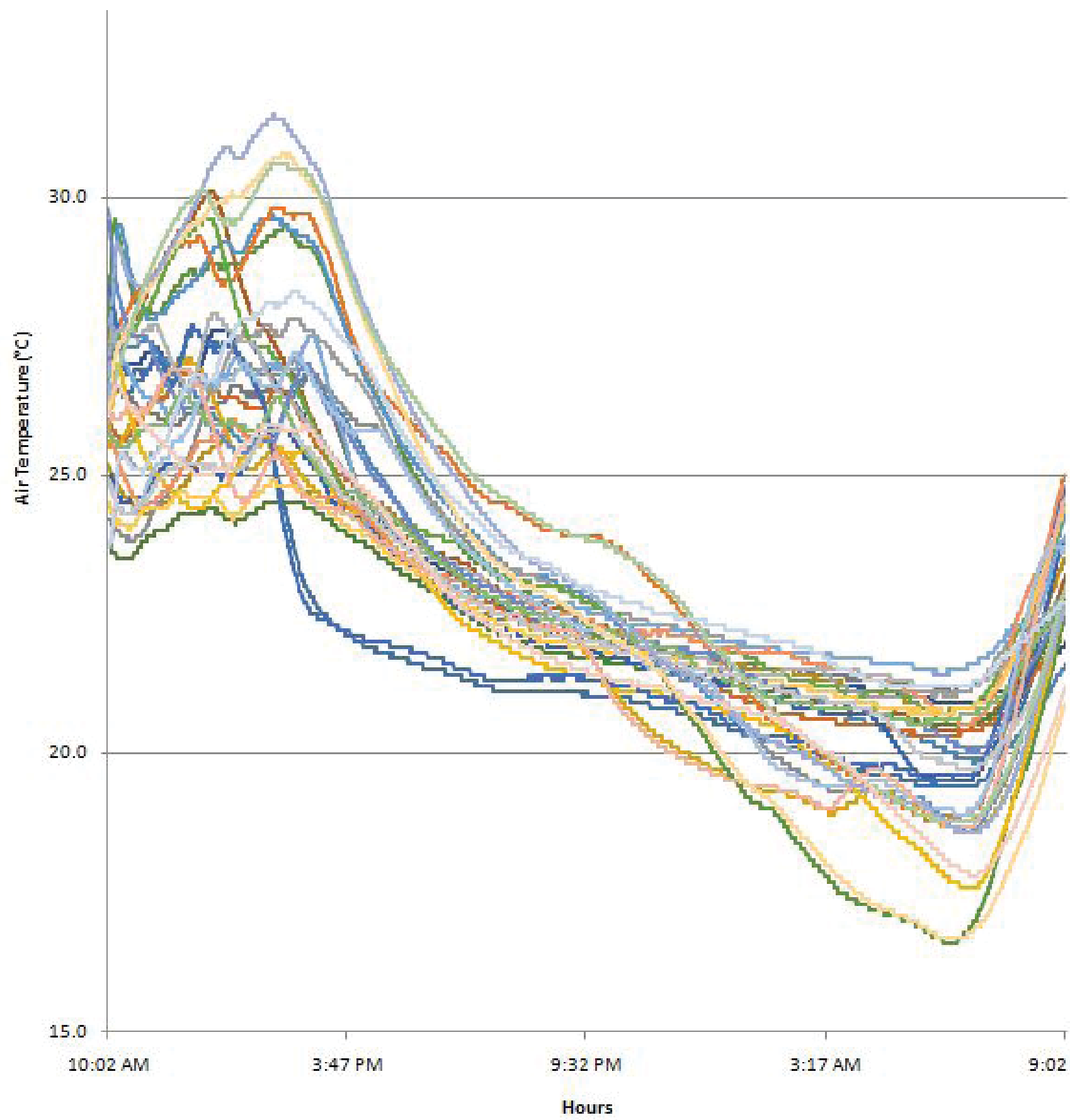

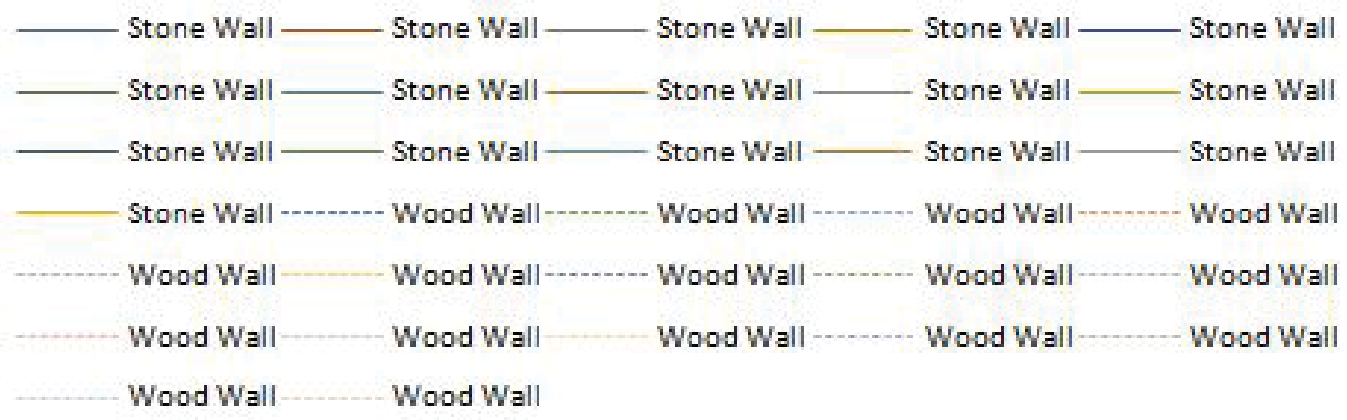

Figure 3: Indoor temperature (stone wall and wood wall models) 


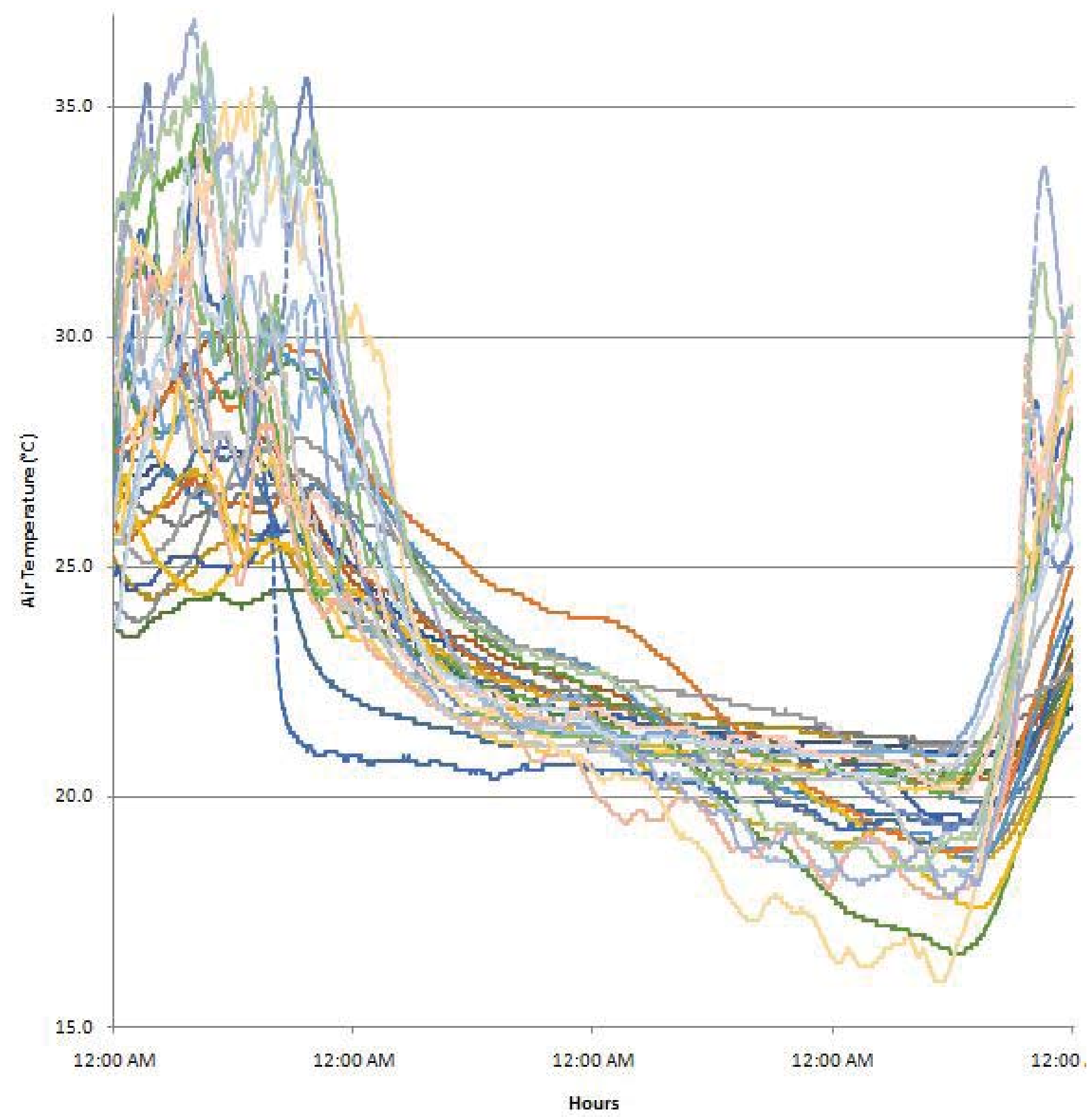

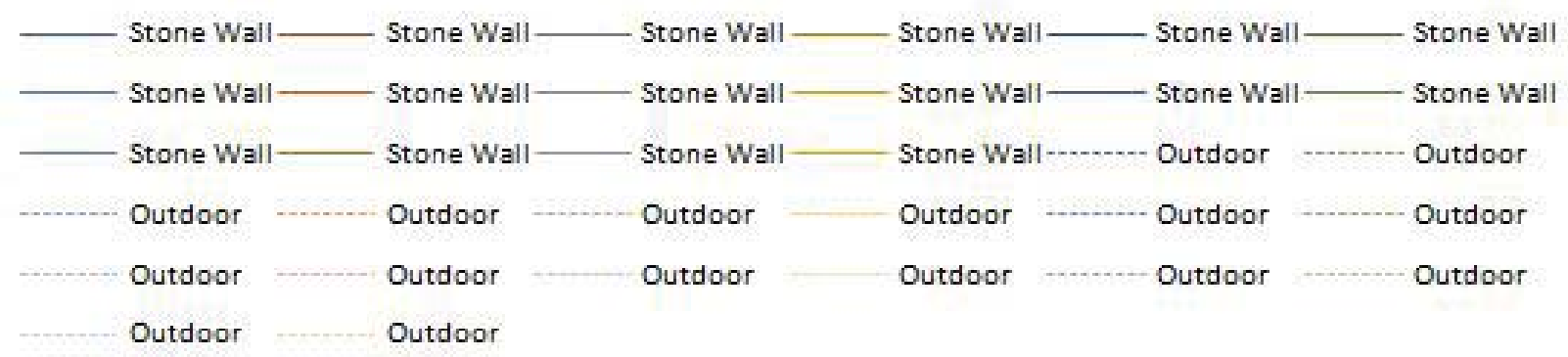

Figure 4: Indoor and outdoor temperature (stone wall models) 

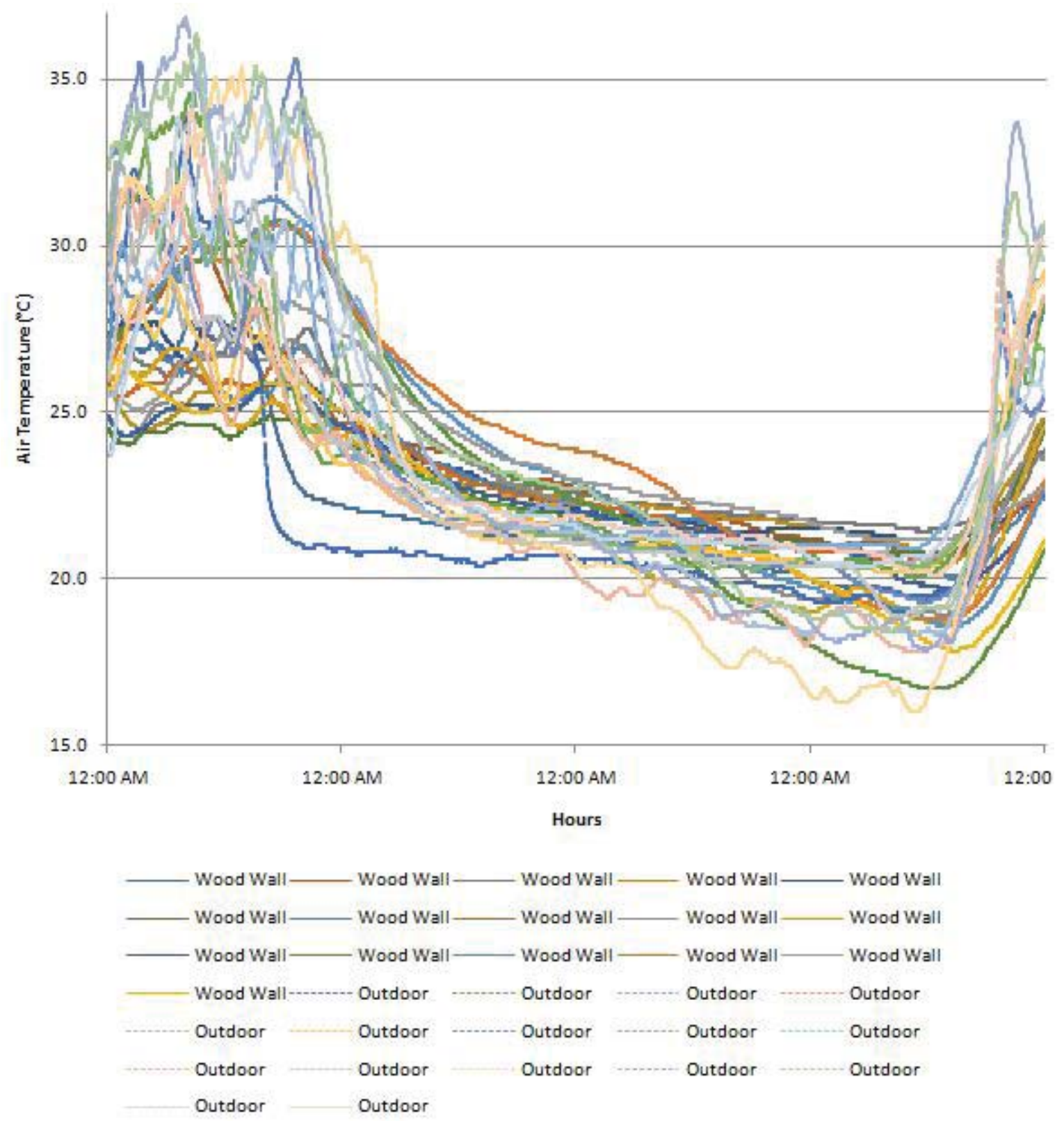

Figure 5: Indoor and outdoor temperature (wood wall models)

research. Beyond these hours, the outdoor temperature seems lower despite its insignificant difference from the indoor.

\section{Comparison of indoor temperatures}

The main buildings are distinguished from their walls, i.e. wood and exposed stone walls. The measurement has been made in the two main buildings with modified roofs and floors. There are a total of 32 building model variations. The measurement results of the two main buildings (wood- and exposed stone-walled) are combined into one graphic, thus 16 graphics are obtained and they show the comparison of indoor temperature of the woodand exposed stone-walled buildings with roof and floor variations.

The wood-walled building, with wood floor and zinc roof seems to have higher temperature than the exposed stone-walled buildings, with wood floor and zinc roof. From 11:00 am to $1: 00 \mathrm{pm}$, the two buildings' temperatures seem almost identical. At 2:00 pm, the wood-walled building's temperature is lower than that of the exposed stone-walled building. From this measurement result, it can be concluded that generally speaking the woodwalled building has higher or warmer temperature than that of the stone-walled building. The measurement in the buildings with wood floor and asbestos roof indicates wider difference in indoor temperature than the measurement result in those building with wood floor and zinc roof. The wood-walled building seems to have lower temperature than the exposed stone-walled buildings for 5 hours, i.e. from 10:00 am to 3:00 pm. The opposite occurs for 19 hours, i.e. the wood-walled building is warmer than the exposed stone-walled building. 


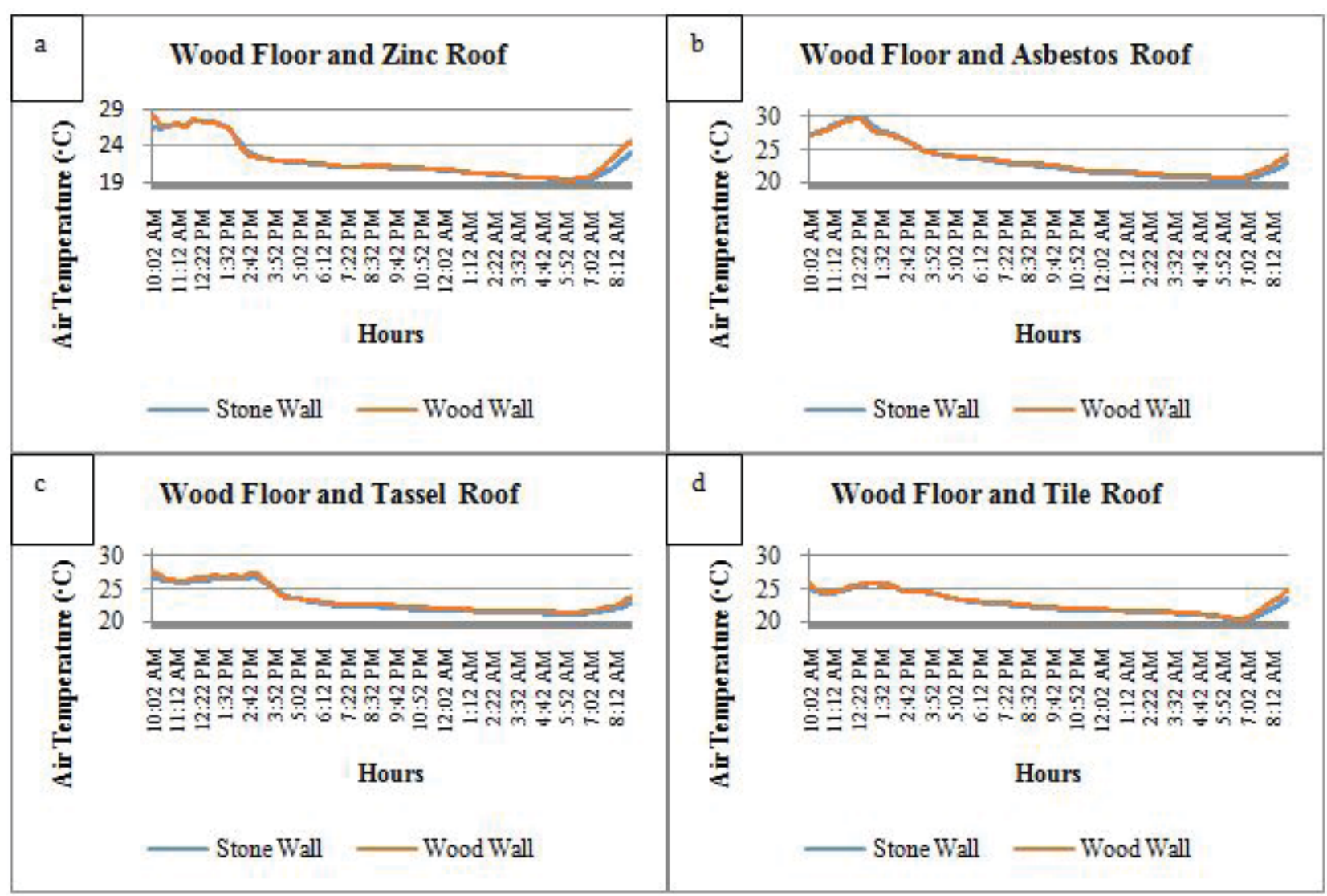

Figure 6: Comparison of indoor temperatures in exposed stone- and wood-walled buildings; (a) Wood Floor and Zinc Roof; (b) Wood Floor and Asbestos Roof; (c) Wood Floor and Thatch Roof; (d) Wood Floor and Tile Roof

The measurement result in buildings with wood floor and thatch roof shows that the wood-walled building is warmer almost at all time than the exposed stone-walled building. For only one hour the wood-walled building looks colder than the exposed stone-walled building, i.e. at 4:00 pm.The measurement in buildings with wood floor and roof tile shows significant difference between the wood and exposed stone-walled buildings. For 4 hours the temperature of wood-wall building seems lower than the exposed stone-walled building. However, the overall result indicates that the wood-walled building has higher temperature than the exposed stone-walled building even if it is insignificant.

Concrete floor and zinc roof become the basis for the next measurement. The two different walled buildings are combined with concrete floor and zinc roof and they produce similar temperatures as the previous measurement results. The wood wall seems to produce warmer temperature than the exposed stone-walled building. During this measurement, the temperature shows no differences from 11:00 to 5:00 pm. Thus, for 19 hours the wood wall's temperature seems warmer. At 1:00 pm, the wood wall's temperature seems the same as that of the exposed stone-walled building. The buildings subjected to measurement are those with concrete floor and asbestos roof. Thus, the wood wall's temperature is warmer than that of the exposed stone wall for 23 hours. The fairly wide difference occurs for 1 hour, i.e. at 07:00-08:00 am.
For 6 hours, the wood wall's temperature is lower than the exposed stone wall. Such phenomenon also occurs at 11:00 m-5:00 pm. Beyond those hours, the wood wall is still warmer than the exposed stone-walled building, i.e. for 18 hours. The wood wall seems to have lower temperature than the exposed stone-walled building at 10:00 am-7:00 pm. This is unlike the measurements of other model variations, yet the wood wall still has warmer temperature than the exposed stone-walled building. For 15 hours the wood wall is still warmer than the exposed stone-walled building.

The temperature variations are seen in the measurement in the buildings with ceramic floor and zinc roof. At 10:00 am-1:00 pm the wood wall's temperature seems higher than the exposed stone-walled building's. At 12:00 am4:00 pm the wood wall has lower temperature than the exposed stone-walled building at a slight difference. At 4:00 pm-12:00 am, the wood wall and exposed stone's temperatures show no differences. At 07:00-08:00 am, a fairly significant temperature difference between the wood wall and exposed stone is seen. The wood wall's temperature is still higher than the exposed stone-walled building's for those with ceramic floor and asbestos roof. Even if at 12:00-2:00 pm the wood wall's temperature is lower than the exposed stone-walled building's, it is still higher at 03:00-08:00 am. As for other times, for 17 hours the wood wall and exposed stone has the same temperature. 


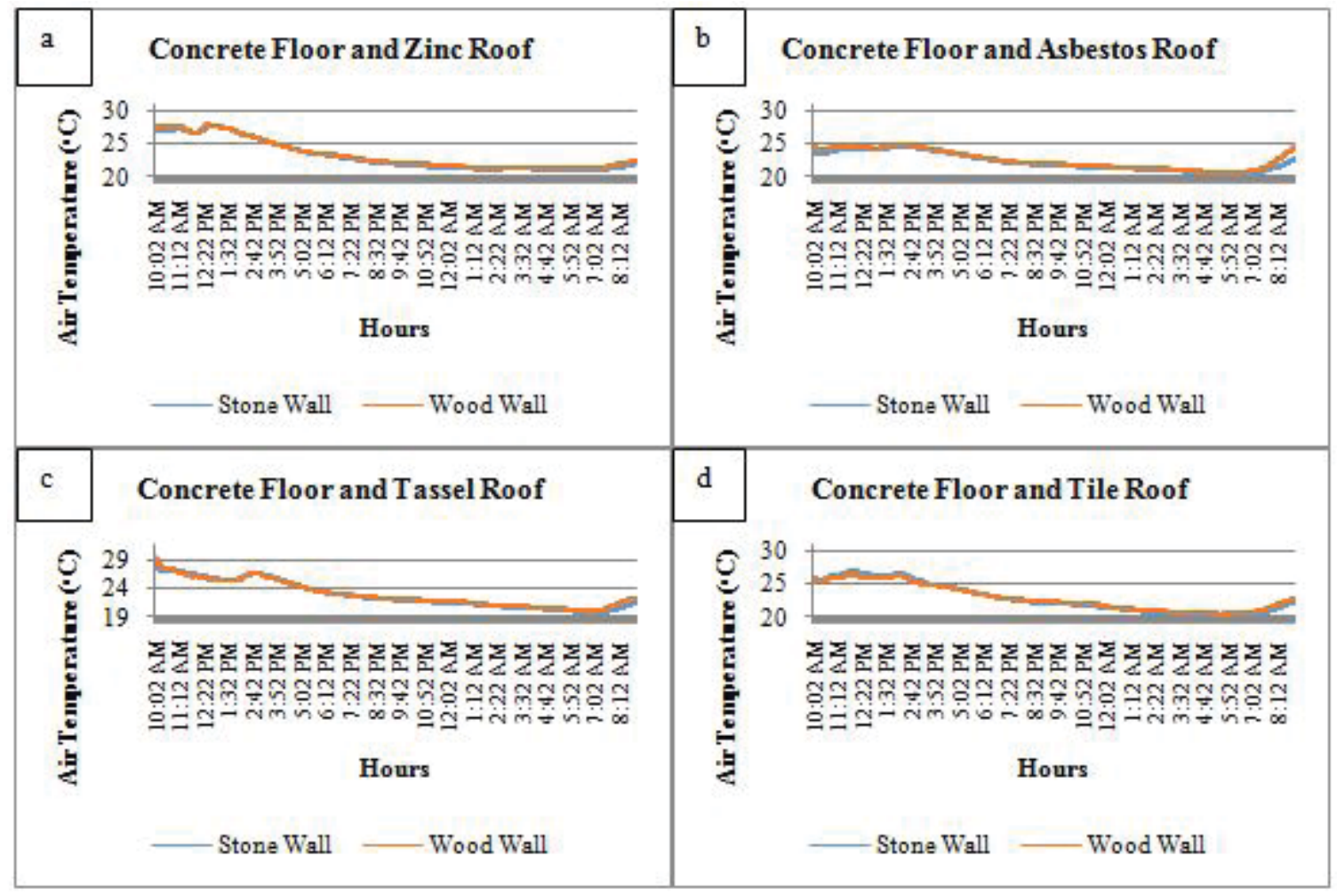

Figure 7: Comparison of indoor temperatures in the exposed stone- and wood-walled buildings;

(a) Concrete Floor and Zinc Roof; (b) Concrete Floor and Asbestos Roof;

(c) Concrete Floor and Thatch Roof; (d) Concrete Floor and Tile Roof

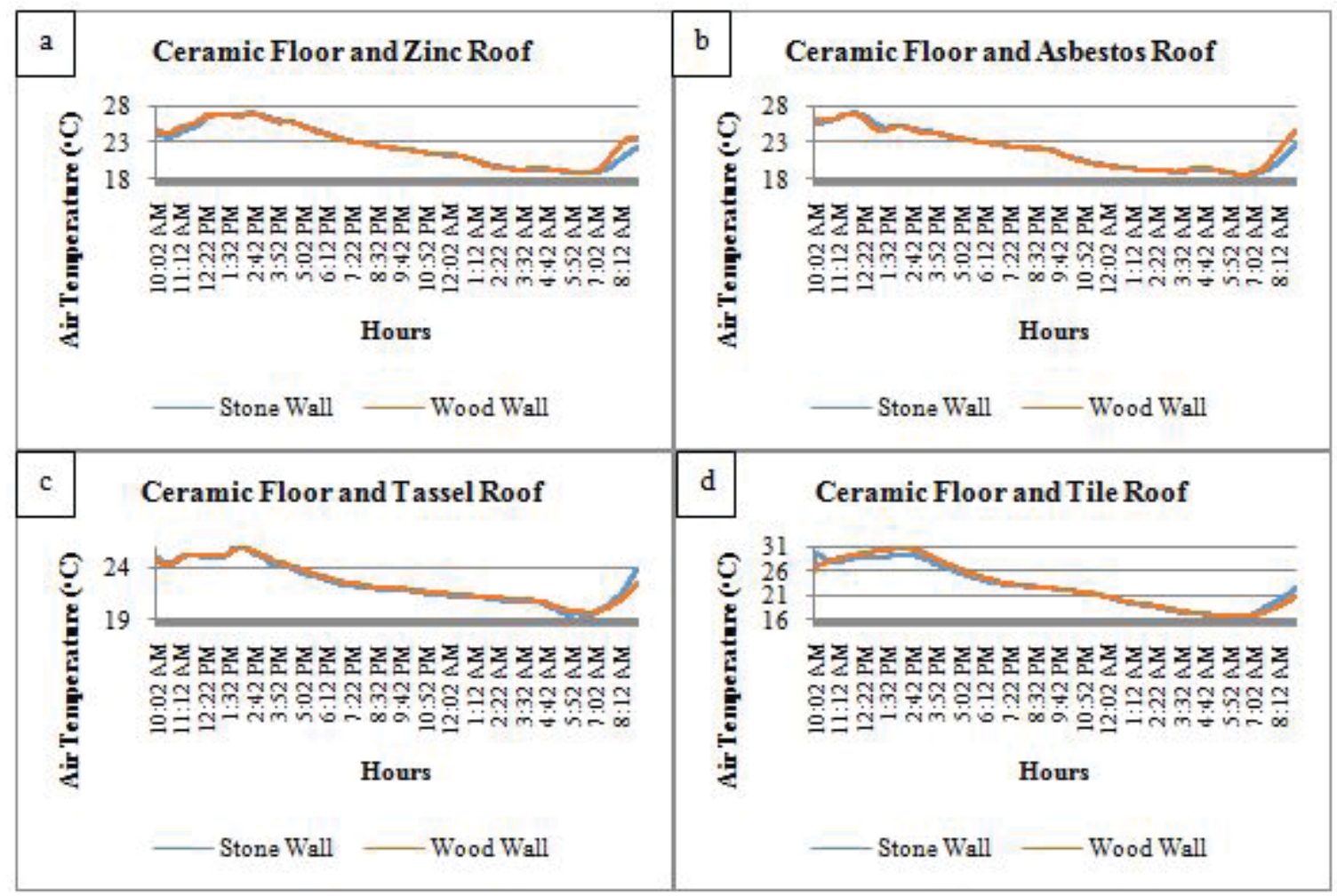

Figure 8: Comparison of indoor temperatures in exposed stone and wood-walled buildings;

(a) Ceramic Floor and Zinc Roof; (b) Ceramic Floor and Asbestos Roof;

(c) Ceramic Floor and Thatch Roof; (d) Ceramic Floor and Tile Roof 


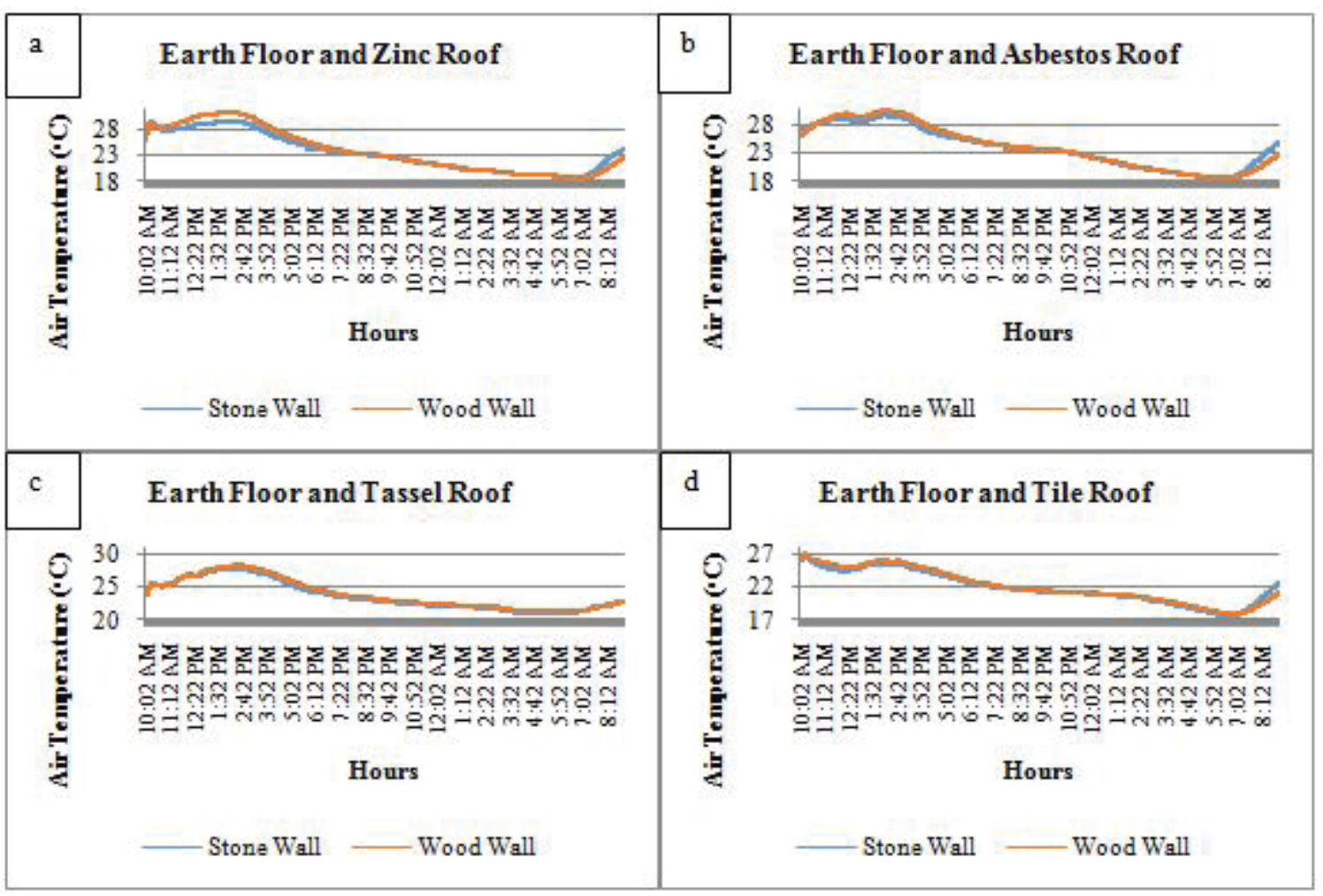

Figure 9: Comparison of indoor temperatures in exposed stone- and wood-walled buildings;

(a) Earth Floor and Zinc Roof; (b) Earth Floor and Asbestos Roof;

(c) Earth Floor and Thatch Roof; (d) Earth Floor and Tile Roof

Insignificant difference in temperature is found in the buildings with ceramic floor and thatch roof. At 2:00 pm05:00 am the wood wall has higher temperature than the exposed stone-walled building. For 15 hours, the wood wall is warmer than the exposed stone-walled building. In the buildings with ceramic floor and roof tile, the wood wall's temperature is lower than that of the exposed stone-walled building for 3 hours. Beyond that, the wood wall's temperature is warmer than the exposed stone.

A fairly significant difference is seen at 11:00 am-7:00 pm in those building with earth floor and zinc roof. For these 8 hours, the wood wall has higher temperature than the exposed stone-walled building. At 07:00-08:00 am the wood wall's temperature seems lower than the exposed stone-walled building's. Those buildings with earth floor and asbestos roof have similar temperature as the other building types. For 8 hours, the wood wall's temperature is higher than that of the exposed stone-walled building. For 3 hours, the wood wall's temperature is lower than that of the exposed stone-walled building. The remainder shows no difference in the wood and exposed stone wall temperatures.

Similar temperature values occur between the wood- and the exposed stone-walled buildings with earth floor and thatch roof. A subtle difference is seen at 11:00-04:00 am with the wood wall's temperature value being higher than that of the exposed stone-walled building. The buildings with earth floor and roof tile also shows no significant difference between the wood- and the exposed stonewalled ones. Overall, it is still seen that the wood-walled building has higher temperature than the exposed stonewalled building.

Both the wood- and stone-walled buildings have not-so-different temperatures. A different temperature movement behavior is seen varied in the set floor and roof. The temperature movement behavior is different at 10:00 am-3:00 pm, thus the analysis of temperature movement is focused during these hours. The buildings with wood floor and zinc roof has temperature not higher than $28^{\circ} \mathrm{C}$. The temperature movement at 10:00 am-3:00 $\mathrm{pm}$ seems sloping at around $27^{\circ} \mathrm{C}$. The buildings with floor wood and asbestos roof have the highest temperature at $30 \mathrm{oC}$. Their temperature movement at 10:00 am3:00 pm seems increasing fairly sharply. The buildings with wood floor and roof thatch have the highest temperature at $27^{\circ} \mathrm{C}$. Their temperature movement at $10: 00$ am-3:00 pm seems sloping at around $26^{\circ} \mathrm{C}$. The buildings with wood floor and roof tile have the highest temperature at $26^{\circ} \mathrm{C}$. Their temperature movement at 10:00 am-3:00 pm seems fluctuating at $25^{\circ} \mathrm{C}$.

In the buildings with concrete rebate floor and zinc roof, at 10:00 am-3:00 pm they seem to have a fairly sloping temperature movement at around $27^{\circ} \mathrm{C}$. The buildings with concrete rebate floor and asbestos roof at 10:00 am-3:00 pm seem to have a sloping temperature movement at around $25^{\circ} \mathrm{C}$. The buildings with concrete rebate floor and thatch roof at 10:00 am-3:00 pm seem to have declining temperature movement from $29^{\circ} \mathrm{C}$ to $26^{\circ} \mathrm{C}$. The buildings with concrete rebate floor and roof tile at 10:00 am-3:00 pm seem to have a sloping temperature move 
ment at $26^{\circ} \mathrm{C}$.

In the buildings with ceramic floor and zinc roof at 10:00 am-3:00 pm, they seem to have sharply increasing temperature movement from $23^{\circ} \mathrm{C}$ to $27^{\circ} \mathrm{C}$. The buildings with ceramic floor and asbestos roof at 10:00 am-3:00 $\mathrm{pm}$ seem to have fluctuating temperature movement at around $25^{\circ} \mathrm{C}$. The buildings with ceramic floor and thatch roof at 10:00 am-3:00 pm seem to have slightly increasing temperature movement from $24^{\circ} \mathrm{C}$ to $26^{\circ} \mathrm{C}$. The buildings with ceramic floor and thatch roof seem to have increasing temperature movement from $26^{\circ} \mathrm{C}$ to $31^{\circ} \mathrm{C}$. In the buildings with earth floor and zinc roof as well as asbestos roof, it is not too different. Both buildings at 10:00 am-3:00 pm seem to have a fluctuating temperature movement at around $29^{\circ} \mathrm{C}$. The building with earth floor and thatch roof at 10:00 am-3:00 pm seem to have an increasing temperature movement from $25^{\circ} \mathrm{C}$ to $28^{\circ} \mathrm{C}$. The buildings with earth floor and roof tile at 10:00 am-3:00 $\mathrm{pm}$ seem to have a fluctuating temperature movement at $25^{\circ} \mathrm{C}$.

These temperature movements will influence the building inhabitants' thermal comfort. The comfortable temperature standard in humans varied, depending on the microclimate in their own environment. The comfortable temperature in research on residence in Cuenca, Equador is $20.12^{\circ} \mathrm{C}$. The comfortable temperature for Church users in Jakarta, Indonesia is $27.7^{\circ} \mathrm{C}$, in museums in Jakarta is $27.7^{\circ} \mathrm{C}$ and in market buildings is $27.3^{\circ} \mathrm{C}$. The comfortable temperature in residences in Yogyakarta is $29.1^{\circ} \mathrm{C}$. The comfortable temperature in Jakarta is $26.4^{\circ} \mathrm{C}$, Bandung $24.7^{\circ} \mathrm{C}$, Makassar $27.7^{\circ} \mathrm{C}$, Medan $27.9^{\circ} \mathrm{C}$, and Surabaya $28.9^{\circ} \mathrm{C}$. Residences in Japan has a comfortable temperature at $27.6^{\circ} \mathrm{C}$ [15-21].

Judging from the building inhabitants' comfortable temperatures in several different cities, it is important to see the climate similarity in the research site. Wonosobo Regency tends to be cold, just like Bandung Municipality, thus the comfortable temperature to be used is $24.7^{\circ} \mathrm{C}$. The indoor temperature values of this research which is close to this comfortable temperature are found in several types of house. These include the wood floor and roof tile, the concrete rebate floor and asbestos roof and ceramic floor, the asbestos roof and earth floor and roof tile. The trend of these four types of house during daytime is that they can create the thermal comfort for their inhabitants from 10:00 am to 3:00 pm. However, in the morning and evening it can be seen that a specific type of house can provide thermal comfort, namely the zinc roof house. The warmest house is the wood-walled building, with earth floor and zinc roof. This is as found in the previously conducted field research [22].

\section{Difference of indoor temperatures}

The temperature difference is calculated per data. The total difference obtained is counted for its average and thus the difference average result between the two types of building is obtained. The temperature difference between wood- and exposed stone-walled buildings shows that most wood buildings have higher emperature than the exposed stone-walled ones. From some of the same roof and floor types, it is found that the roof and floor type

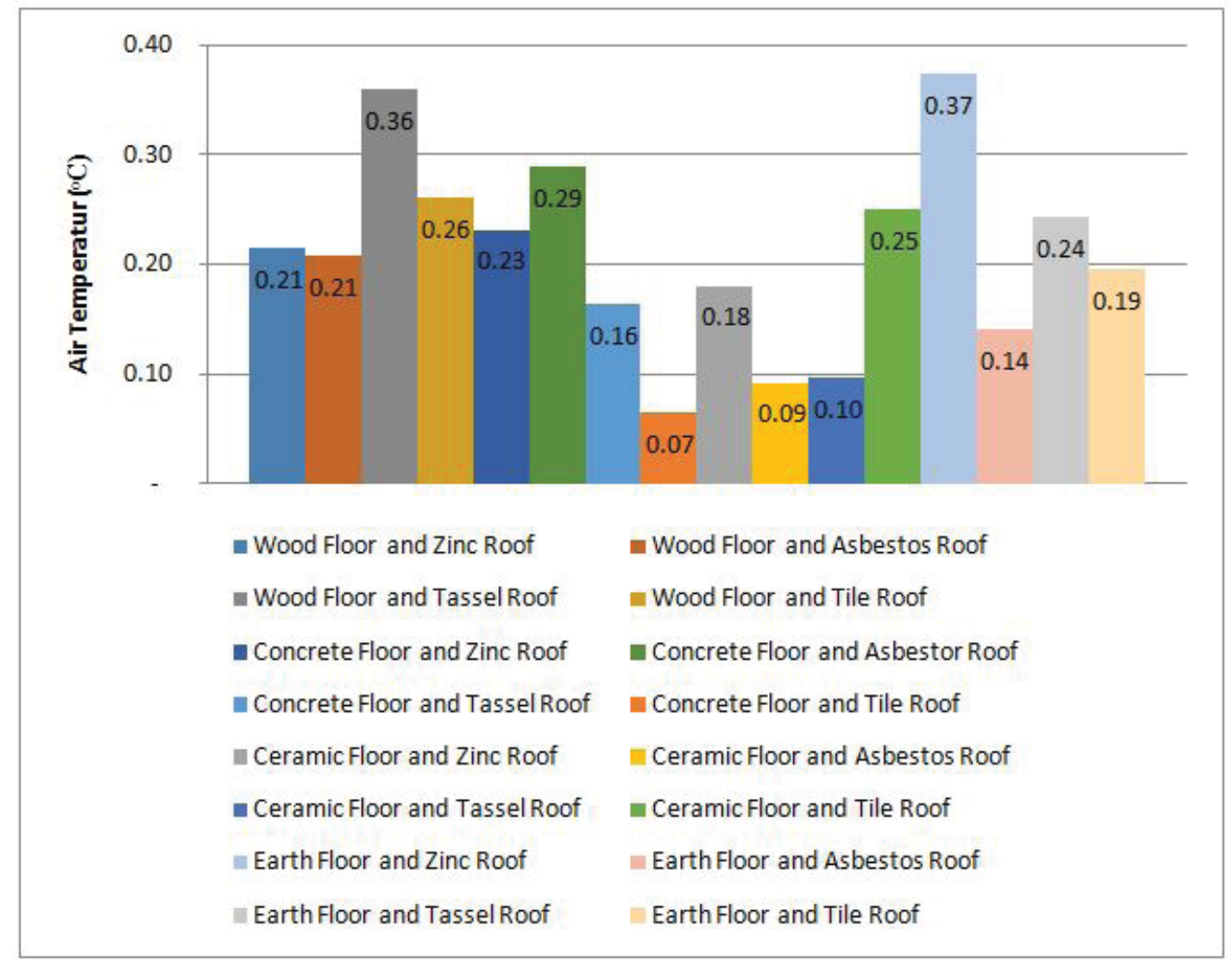

Figure 10: Temperature difference between wood- and exposed stone-walled buildingsf 
Table 2: Rank of temperature differences of wood- and exposed stone-walled buildings

\begin{tabular}{|l|c|c|}
\hline \multicolumn{1}{|c|}{ Building variation } & Difference & Rank \\
\hline Wood Floor and Zinc Roof & 0.21 & 8 \\
\hline Wood Floor and Asbestos Roof & 0.21 & 9 \\
\hline Wood Floor and Thatch Roof & 0.36 & 2 \\
\hline Wood Floor and Tile Roof & 0.26 & 4 \\
\hline Concrete Floor and Zinc Roof & 0.23 & 7 \\
\hline Concrete Floor and Asbestos Roof & 0.29 & 3 \\
\hline Concrete Floor and Thatch Roof & 0.16 & 12 \\
\hline Concrete Floor and Tile Roof & 0.07 & 16 \\
\hline Ceramic Floor and Zinc Roof & 0.18 & 11 \\
\hline Ceramic Floor and Asbestos Roof & 0.09 & 15 \\
\hline Ceramic Floor and Thatch Roof & 0.10 & 14 \\
\hline Ceramic Floor and Tile Roof & 0.25 & 5 \\
\hline Earth Floor and Zinc Roof & 0.37 & 1 \\
\hline Earth Floor and Asbestos Roof & 0.14 & 13 \\
\hline Earth Floor and Thatch Roof & 0.24 & 6 \\
\hline Earth Floor and Tile Roof & 0.19 & 10 \\
\hline
\end{tabular}

with the highest difference is zinc roof and earth floor. The highest difference produced is $0.37^{\circ} \mathrm{C}$, and the lowest difference is found at $0.07^{\circ} \mathrm{C}$. The zinc roof and earth floor combination has been one of the residence types in rural areas. Residences in rural areas in mountain slopes are owned by the underprivileged. Most underprivileged people residing in inland in mountain slopes uses the residence type with zinc roof and earth floor. This matches the finding which shows that rural residences can create thermal comfort [23].

Zinc roof is deemed capable of conducting high heat since it is also a conductor metal. Earth floor contains the elements which can also maintain the heat. A building with either wood or exposed stone walls, when combined with several zinc roof-earth floor variations will provide thermal comfort to the inhabitants of buildings a mountain slope. The temperature difference between outdoor and indoor temperature becomes a reference for determines the thermal performance of the building [24].

\section{CONCLUSION}

Materials become an important element in determining the building thermal performance. Materials can be applied in building envelope which is deemed as a bridge between the external and internal environments of the building. Building envelope modification is highly needed to obtain a building design capable of creating thermal comfort. The research results indicate that the most appropriate alternative building envelope design for mountainous residences is a residence with wood wall, zinc roof and earth floor. Modification of the building envelope material is the most convenient alternative for mountain- ous regions. This is in accordance with the character of the countryside. This building design is just the type of residences in rural areas.

However, this earth floor has a weakness in its hygiene thus the use of earth floor for modern people will be barely acceptable. A modification needs to be made to a floor material which can replace soil without reducing its ability in conducting heat. Further research is needed for material modification to be accepted by all people groups.

\section{ACKNOWLEDGMENT}

Thanks to the Republic of Indonesia Ministry of Research, Technology and Higher Education for providing research funding. Grant number 025/L6/AK/SP2H/PENELITIAN/2019.

\section{REFERENCES}

1. Dernie, D., Gaspari, J. (2015). Building envelope over-cladding: impact on energy balance and microclimate. Buildings, 5, 715-735.

2. Rosso, F., Pisello, A.L., Cotana, F., Ferrero, M. (2014). Integrated thermal-energy analysis of innovative translucent white marble for building envelope application. Sustainability, 6, 5439-5462.

3. Carletti, C., Pierangioli, L., Sciurpi, F., Salvietti, A. (2018). Comparison among detailed and simplified calculation methods for thermal and energy assessment of the building envelope and the shadings of a new wooden nZEBhouse. Sustainability, 10, 476.

4. Alaidroos, A., Krarti, M. (2015). Optimal design of residential building envelope systems in the Kingdom of Saudi Arabia. Energy and Buildings, 86, 104-11.

5. Badarnah, L. (2017). Form follows environment: biomimetic approaches to building envelope design for environmental adaptation. Buildings, 7, 40.

6. Albatayneh, A., Alterman, D., Page, A., Moghtaderi, B. (2017). The impact of the thermal comfort models on the prediction of building energy consumption. Sustainability, 10, 3609.

7. Widiastuti, R., Caesarendra, W., Prianto, E., Budi, W.S. (2018). Study on the leaves densities as parameter for effectiveness of energy transfer on the green facade. Buildings, 8, 138.

8. De Berardinis, P., Rotilio, M., Capannolo, L. (2017). Energy and sustainable strategies in the renovation of existing buildings: an Italian case study. Sustainability, 9, 1472.

9. Mohammad, S., Shea, A. (2013). Performance evaluation of modern building thermal envelope designs in the semi-arid continental climate of Tehran. Buildings, 3, 674-688. 
10. Suárez, R., Escandón, R., López-Pérez, R., León-Rodríguez, Á.L., Klein, T., Silvester, S. (2018). Impact of climate change: environmental assessment of passive solutions in a single-family home in Southern Spain. Sustainability, 10, 2914.

11. Choi, D.H., Kang, D.H. (2018). Indoor/outdoor relationships of airborne particles under controlled pressure difference across the building envelope in Korean multifamily apartments. Sustainability, 10, 4074.

12. Bodach, S., Lang, W., Hamhaber, J. (2014). Climate building design strategies of vernacular architecture in Nepal, Energy Build, 81, 227-242

13. Huang, L., Hamza, N., Lan, B., Zahi, D. (2016). Climate-responsive design of traditional dwellings in the cold-arid regions of Tibet and a field investigation of indoor environments in winter, Energy Build, 128, 697-712

14. Hermawan. (2014).Karakteristik rumah tinggal tradisional di daerah pegunungan Jawa Tengah. Jurnal PPKM UNSIQ, 3, 212-219

15. Molina, F.Q. Yaguana, D.B. (2018) Indoor environmental quality of urban residential buildings in Cuenca-ecuador: comfort standard. Buildings, 8, 90.

16. Karyono, T.H., Sri, E., Sulistiawan, J.G., Triswanti, Y. (2015). Thermal comfort studies in naturally ventilated buildings in Jakarta, Indonesia. Buildings, 5, 917-932.

17. Feriadi, H., Wong, N.H. (2004). Thermal comfort for naturally ventilated houses in Indonesia. Energy Build, 36, 614-626.
18. Karyono, T.H. (1995). Thermal comfort for the Indonesian workers in Jakarta. Build. Res. Inf, 23, 317-323.

19. Karyono, T.H. (2008). Bandung thermal comfort study: assessing the applicability of an adaptive model in Indonesia. Archit. Sci. Rev, 51, 60-65.

20. Karyono, T.H. (2015). Predicting comfort temperature in Indonesia, an initial step to reduce cooling energy consumption. Buildings, 5, 802-813.

21. Rijal, H.B. (2014). Investigation of comfort temperature and occupant behavior in Japanese houses during the hot and humid season. Buildings, 4, 437452.

22. Hermawan,Sunaryo, Kholil, A. (2018). A thermal performance comparison of residential envelopes at the tropical highland for occupants' thermal comfort. IOP Conf. Ser.: Earth Environ. Sci, 200, 012034

23. Lu, S., Wang, R., Zheng, S. (2017). Passive optimization design based on particle swarm optimization in rural buildings of the hot summer and warm winter zone of China. Sustainability, 9, 2288.

24. Hermawan, Prianto, E., Setyowati, E. (2019). Indoor temperature prediction of the houses with exposed stones in tropical mountain regions during four periods of different seasons. International Journal of Civil Engineering and Technology (IJCIET), 10, 05, 604-612. 